\title{
Some Critical Analysis of the Japanese "Legal Transplant" Concept: From the Legal Geography Perspective
}

\begin{abstract}
Kunihiko Yoshida*
Japanese Civil Code is commonly considered a good example of "legal transplant" from European law, and now it exerts influence upon Southeast Asian law in the same way in recent years. However, "legal transplant" phenomena should be critically reexamined from the legal geography perspective. In this process, the systemic problem of legal marginalization of ethnic minorities, such as indigenous peoples in Japan, and the legal colonization of neighboring countries in the past could be fairly analyzed.
\end{abstract}

Keywords: legal transplant, legal geography, Indigenous peoples, colonialism

\section{Preface}

The Japanese Civil Code was considered a "fruit of comparative jurisprudence" in the early 20th century by Nobushige Hozumi. ${ }^{1}$ As this phrase shows, Japanese law was and has been one of the most successful cases of legal transplant.

Even in the 1960-1980s, research of "legal transplants" attracted Japan's top mainstream comparative and civil law scholars, most notably, Yoshiyuki Noda ${ }^{2}$, Zentarou Kitagawa ${ }^{3}$, and Eiichi Hoshino ${ }^{4}$, in Japan. In civil law, German law (BGB) was formerly considered the mother code of Japanese civil law, but it turned out that Japanese law was originally transplanted from French code thanks to G. E. Boissonade. Later, some British case law was added to the previous civil code (named the "Boissonade Civil Code") through the efforts of Professor

\footnotetext{
* Professor of Law, Hokkaido University, Hokkaido, Japan; Permanent Visiting Professor of Law, Nanjing Normal University, Jiangsu, China. I am indebted to Professor Rob Leflar of the University of Arkansas Law School and Tokyo University for his extensive comments on a draft of this paper. All the views expressed in this paper are mine, not necessarily his.

My thanks will also go, at least, to Professor Setsuo Miyazawa of University of California, Hastings, who offered me the opportunity to present this paper on this important topic of "legal transplant" at the ALSA annual meeting on December 14th, 2019, with subsequent publication, and Professor Sandy Kedar of Haifa University, Israel, my good intellectual friend in the same vein in Middle East, who has continuously incited me to work on this stimulating "legal geography" field for the last several years.

1 Nobushige Hozumi, Lectures on the New Japanese Civil Code: As Material for the Study of Comparative JURISPRUDENCE (Tokyo: Maruzen, 1912).

${ }^{2}$ Yoshiyuki Noda, The Reception of Foreign Laws in Japan, in: MASAMI ITOH ED., ForeIGN LAW AND JAPANESE LAW (MODERN LAW Vol. 14) (Tokyo: Iwanami, 1966). Professor Noda (1912-1985) was a pioneering scholar of comparative law and comparative legal culture, focusing on French law.

3 Professor Kitagawa (1932-2013) taught civil law at Kyoto University (1962-1996). His major work is about the Structure of Contractual Liability (1963), but his work on the reception of the German civil law scholarship in Japan (REZEPTION UND FORTBILDUNG DES EUROPAEISCHEN ZIVILRECHTS IN JAPAN (Alfred Metzner Verlag, 1970) has also been considered epoch-making.

4 Professor Hoshino (1926-2012), a civil law professor of Tokyo University, deconstructed the German influence [Germany-oriented bias of Japanese civil law scholarship] from the French law perspective since the 1960s. See, Eiichi Hoshino, The History of Civil Law Scholarship, Legal Classroom (Hogaku Kyositsu), Vols. 8-11 (1981).
} 
Hozumi, one of the drafters of the present Japanese Civil Code mentioned at the beginning, who had experience as a barrister in the United Kingdom before the codification of the present Japanese Civil Code 120 years ago.

Why Japanese Civil Law scholarship moved geographically toward German law in the early 20th century by forgetting about the origin of the Japanese Civil Code has been considered mysterious. Here are some hypotheses: (1) the relationship between this academic bias and the political propensity of the Japanese society and government towards Japanese and German military relationships; (2) a collective academic group orientation towards Germany scholarship across academic fields; (3) the intrinsic intellectual appeal of German scholarship, especially Jewish German legal scholar, such as Max Rheinstein; and (4) the monotonous atmosphere of the French "l'école de l'exégèse" in the 19th century for Prof. Masaakira Tomii, a precursor of German legal research after his experience at Lyon University in France, while "l'école scientifique" was thought-provoking for Ume who later studied there from the end of 19 th century. ${ }^{5}$

A similar methodology, named "legal circle" analysis was also the main concern among notable legal comparativists, especially Kiyoshi Igarashi ${ }^{6}$ of Hokkaido University, a pioneering legal comparativist in Japan, and Masao Ohki ${ }^{7}$, and originally, German legal comparativists Konrad Zweigert and Hein Koetz ${ }^{8}$.

\section{Legal Geography Analysis}

\section{A. In General}

However, a new form of analysis named "legal geography" started critical discussions of legal transplant concepts. Legal geography analysis, first proposed by Nicholas Blomley, takes account of power relationships, especially colonial/neo-colonial negative legacies. Professor Blomley argues that place-bound ties and roots become contingent and ephemeral and that in the complexity and ambiguity of social life, the legal agent evaluate space in various ways and thus legal spaces are embedded in broader social and political claims, so that geographies of law can be powerful, and even oppressive?

Moreover, geographical studies about race and politics offered by Richard Ford ${ }^{10}$ and Douglas Massey \& Nancy Denton ${ }^{11}$ have attracted attention among critical race theorists. These studies have been contrasted to the traditional non-political analysis mentioned above.

\footnotetext{
${ }^{5}$ See, infra note 18, for details about Professor Ume's involvement with Korea. With Prof. Hozumi, Professors Tomii and Ume were the three prominent drafters of our present civil code.

${ }^{6}$ Kiyoshi Igarashi, Introduction to Comparative Law (Tokyo: Nihon Hyoron Pub. Co., 1968); Problems of Comparative Civil Law (Tokyo: Ichiryu Pub. Co., 1976); Handbook of Comparative Law (Tokyo: Keisou Pub. Co., 2010). Prof. Igarashi (1925-2015) of civil law and comparative law at Hokkaido University is a pioneering legal comparativist and worked on the legal circle. His work at his age of 35 on comparative marital property and contractual warranty based on Ernst Rabel is especially famous in Japan. But his methodology of comparative law is apolitical.

7 E.g., Masao Ohki, Lectures on Comparative Law (Tokyo: Tokyo Univ. Pub. Co., 1992). See also, Tsuyoshi Kinoshita, Comparative Legal Culture (Tokyo: Yuhikaku Pub. Co., 1999).

${ }^{8}$ Konrad Zweigert \& Hein Koetz, Einfuehrung in die Rechtsvergleichung auf Dem Gebiete des Privatrechts (3. Aufl.) (Mohr, 1996) (Trans. by Tony Weir), Introduction to Comparative Law (Oxford: Oxford Press, 1998). See also, Rene DAVID, Les GRANDS SYSTEMES DE DROIT CONTEMPORAINS (Paris: Dalloz, 1964); RENE DAVID AND John BRIERLY, MAJOR LEGAL SYSTEMS IN THE WORLD TODAY (3rd ed.) (London: Stevens, 1985).

9 Nicholas Blomley, Law, SPACE AND the Geographies OF Power (London: Guilford Press, 1994), pp. ix, xi-xii.

${ }^{10}$ Richard Ford, The Boundaries of Race: The Political Geography of Legal Analysis, 107 HARV. L. REV. 1841 (1994).

11 Douglas Massey and Nancy Denton, American Apartheid: Segregation and the Making of the Underclass (Cambridge: Harvard University Press, 1993).
} 


\section{B. The Application of Legal Geography Analysis to the Bedouin Village Case}

This critical method has already been applied to many contexts, such as Middle East Bedouin land conflicts in Israel by Alexandre Kedar (Haifa University) ${ }^{12}$ and Ronen Shamir (Tel Aviv University) ${ }^{13}$. They focus on the violence of Israeli law when it is applied geographically to the ethnic minority in Negev Desert irrespectively of their legal practices, especially ignoring their traditional land title.

I myself visited an unrecognized Bedouin's village named Umm-Al-Hiran for a meeting with its village master in May 2017 thanks to Prof. Kedar's kindness. Umm-Al-Hiran is located about 20 km East of Be'er Sheva, the capital city of the Negev Desert. The Israeli government has a project to displace unrecognized villagers into planned cities, such as Hurah. The legal violence towards them is beyond description ${ }^{14}$. Its legal practice named Dead Negev Doctrine, an Israeli version of the terra nullius doctrine or the discovery doctrine ${ }^{15}$, itself is violent, but its enforcement process is destructive. Especially the tragedy of a local village teacher, Yaakub Abu-Elkiah (Yacoub Abu Al-Qia'an)'s death on January 18th, 2017, should be memorable. Abu-Elkiah, a prominent high school teacher, was killed at the age of 47 years by the Israeli police and army when his house was attacked and destroyed all of sudden early in the morning before dawn ${ }^{16}$. His family were still living under the blue tent when I visited there (see, the picture below [Figure 2]).

Dean James Anaya of the University of Colorado Law School, a previous special rapporteur of the UN Declaration on the Rights of Indigenous Peoples in 2007, also visited this unrecognized village and met with the same village master in March 2017, to no avail. The villagers might be evacuated and their houses almost demolished in the spring of 2019 for a new Jewish community of Hiran, according to recent newspaper articles. ${ }^{17}$

\footnotetext{
12 Alexandre Kedar, Ahmad Amara and Oren Yiftachel, Emptied Lands: A Legal Geography of Bedouin Rights in THE NegEv (Stanford: Stanford University Press, 2018). See also, Alexandre Kedar, On the Legal Geography of Ethnocratic Settler States: Notes Towards a Research Agenda, in: JANE Holder \& CAROlYN HARRISON EDS., LAW AND GEOGRAPHY (CURRENT Legal Issues Vol. 5) (2002) 401.

${ }^{13}$ Ronen Shamir, Suspended in Space: Bedouins under the Law of Israel, in: NichOlas Blomley ED., The LEGAL GEOGRAPHY READER (Oxford: Blackwell, 2001) 135-. Professor Shamir emphasizes the ordering of space that derives from intellectual conceptualism as an act of violence (p. 141), by citing Eco's work (UMBERTO ECO, FoUCAULT'S PENDULUM [New York: Harcourt, 1989] 109).

${ }^{14}$ On my visit at Bedouin's unrecognized village of "Umm-Al-Hiran" in May 2017, I met with its village master Salim Abu-Elkian over Bedouin coffee. His villagers were about to be evicted to designated planned townships, such as Hurah City any day. However, many villagers felt eviscerated to hear the government displacement plan, to use his words. See, Kunihiko Yoshida, The Displacement of the Bedouin People, the Indigenous People in Israel, and Some Observation of Recent Research Movements, in: Transformation of Society and Challenges of Civil Law Scholarship Vol. 2 (Tokyo: Seibundo Pub. Co., 2018) 529-.

15 Terra nullius is a Latin expression meaning "nobody's land", and the person who discovers and occupies terra nullius acquires property according to the discovery doctrine. The Dead Negev Doctrine (DND), the traditional land titles and legal assertions of inhabitance, grazing, and cultivation by Negev Bedouins are considered "dead", with their "rightful" owner being the Jewish state. KEDAR ET AL., supra note 12, at 12-.

${ }^{16}$ See, e.g., https://en.wikipedia.org/wiki/Umm_al-Hiran.

${ }^{17}$ See, e.g., Almong Ben Zikri, Israel to Evacuate Long-Disputed Bedouin Village Umm-Al-Hiran in April, HAARETZ, May 22nd, 2018; Vered Lee, Bedouin Women Capture Their Village's Final Moments Before It's Demolished by Israel, HAARETZ, April 1st, 2019.
} 


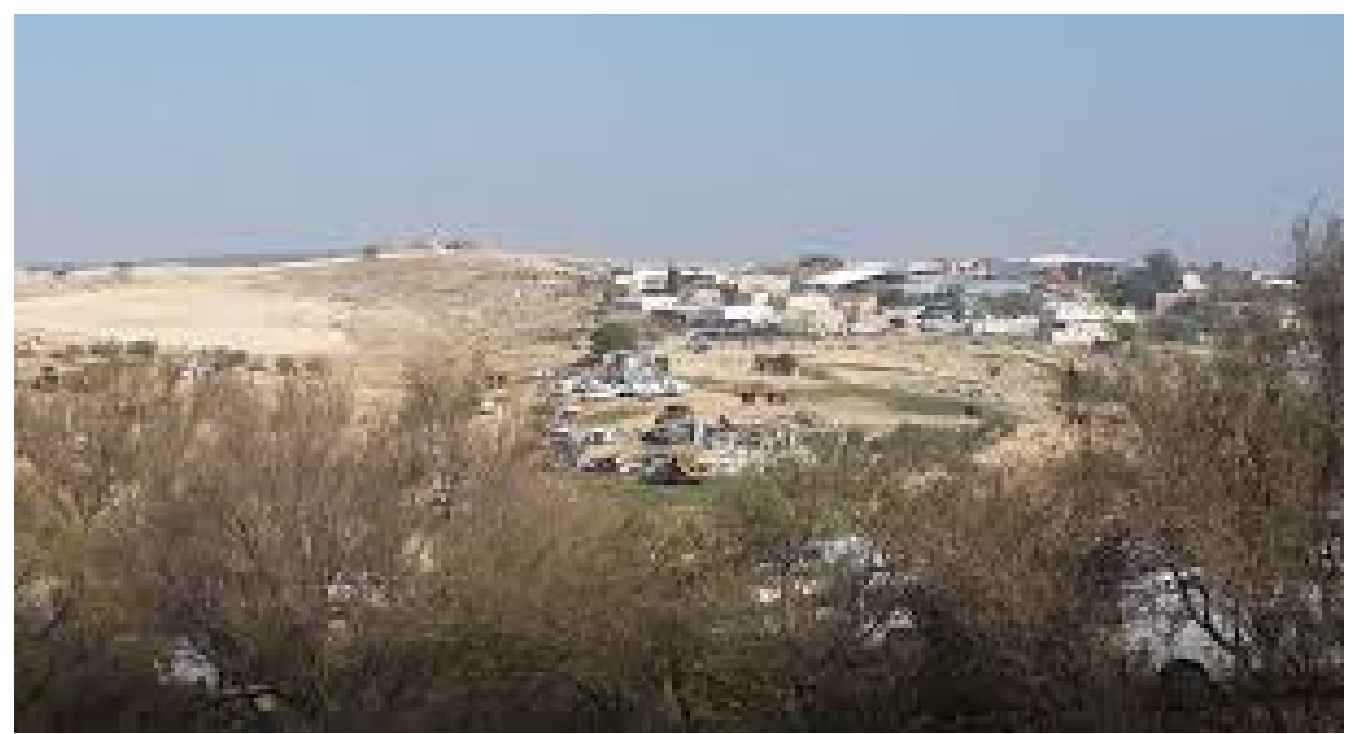

Figure 1. Umm-Al-Hiran.

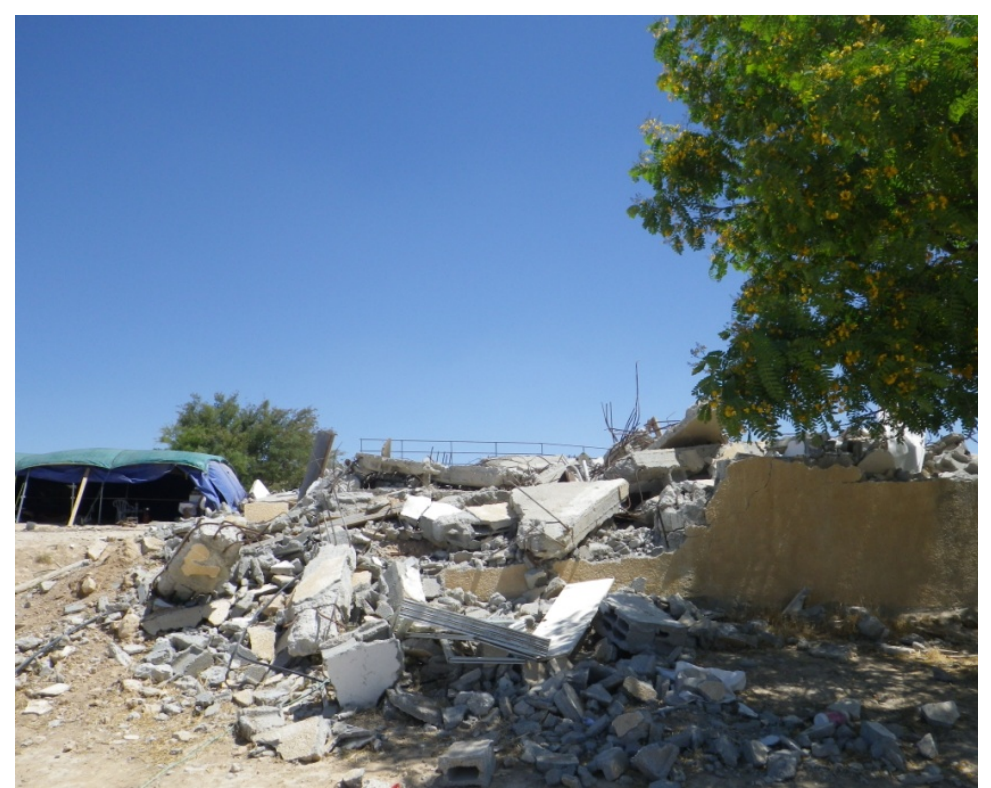

Figure 2. The destruction of Yaakub Abu-Elkiah's (Yacoub Abu Al-Qia'an) residence.

\section{Japanese Property Tragedy Regarding an Ethnic Minority}

Likewise, in the East Asian context, the legal geography perspective will show us a thought-provoking theoretical framework to reconsider past legal transplants. For example, Hokkaido Former Natives Land Protection Act of 1899 and the land investigation project in Korean peninsula started by Professor Ume ${ }^{18}$ in the

\footnotetext{
${ }^{18}$ Professor Kenjirou Ume (1860-1910), who died at the age of 49 years in Korean peninsula, was a member of the intellectual legal elite and contributed outstandingly to the present Japanese Civil Code as one of its three prominent drafters. However, he supported the colonial property system in Korean peninsula as a councillor and protégé of Prime Minister Hirofumi Itoh assassinated at Harbin station by An Jung-Geun in 1909. For the critical analysis of Ume, see, Chun Jeon Hyeou, Kenjirou Ume and Korean Modern Legislative Project, 70(7) HANREI JiHOU 57 (1998).
} 
1910s should be indispensable cases to reconsider the colonial structure of Japanese legal transplants, even though they have continued to be neglected by most Japanese legal scholars.

\section{A. (Case 1): The Hidden Ainu Property Dispute \\ (1) In general}

There was the terra nullius doctrine (the discovery doctrine) regarding Ainu indigenous property, and it still continues as the basis of the present Ainu policy: The Japanese government still rejects the reparations approach of the United Nations Declaration on the Rights of Indigenous Peoples (UNDRIP in 2007). The government's past injustice is still hidden.

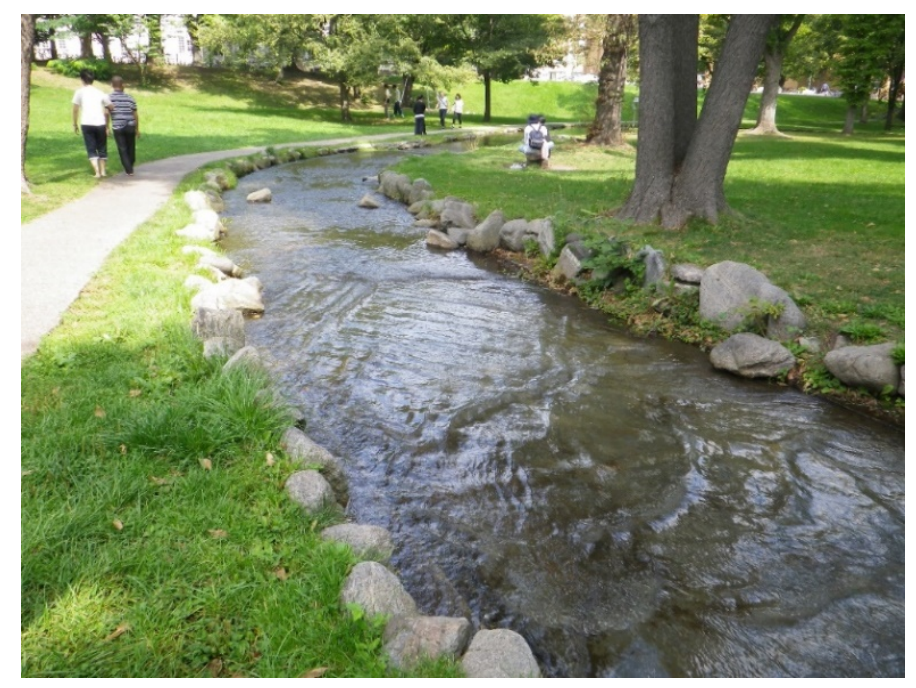

Figure 3. Sakushu-Kotoni River.

For example, Hokkaido University has been a tourists' spot as one of the most spacious and the most beautiful campuses in Japan, but very few people know that the campus used to be an Ainu village and the university was established after the conquest of the Ainu people there. It still plays a negative role of colonialism even nowadays. The name of Sakushu-Kotoni River running in the Central Lawn of Hokkaido University, comes from the Ainu family who originally lived in our campus before their conquest by the Meiji Japanese government. A ceremony for the international repatriation of Ainu ancestral remains was held at the Japanese Embassy in Berlin in 2017, 138 years after they were stolen from the Ainu tomb in the campus by a German traveler, but Hokkaido University still rejects to return it to Ainu relatives. ${ }^{19}$

\section{(2) Problems of the Hokkaido Former Natives Act}

The Hokkaido Former Natives Land Protection Act in 1899, modeled on the allotment policy made by the Dawes Act in 1887 in the United States, continued effective until 1997. However, without any previous treaties with the Ainu people, there was no reservation for them, and their allotment size was much smaller and its method was different than the case for native Americans. Furthermore, due to restrictions on land transfer and mortgage, the Ainu people could not obtain loans from banks, as has been the case of redlining for African American people in the United States. ${ }^{19}$ On this issue, see, Kunihiko Yoshida, Why Can Ainu Ancestral Remains Not Be Returned to the Ainu People: From the
German Repatriation Case, 908 Human Rights \& Buraku IssuEs 14 (2018). 
The basic Ainu land statute of 1899 mentioned above was based on the Dawes Act of 1877 . According to the 1899 law, a small tract of land ( $5 \mathrm{ha}=12.38$ acres) was allotted to each Ainu family for promoting agriculture under the stringent condition of cultivation within 15 years. Few Ainu families met that condition. The law's land grant to the Ainu was much smaller than that to the Native Americans, who under the Dawes Act received 160 acres (family leaders), 80 acres (adults), or 40 acres (children). The 1899 Law should also be contrasted to the law pertaining to mainlanders migrating to Hokkaido from mainland Japan, who could acquire one million hectares of lands. ${ }^{20}$ It was exactly the unequal and illegal treatment in terms of international human right law.

Furthermore, there was a big difference between Native Americans and the Ainu people. For American Indians, treaties allotted to them fairly extensive reserved lands. By contrast, the Ainu people were displaced from their original coastal areas to mountainous barren lands allotted anew by the statute. Before the statute of 1899, already in the 1870s, by the zigzag process of the Hokkaido Land Regulation of 1872 and the Hokkaido Land Security Ordinance of 1877 , the Ainu lands were considered to be state lands under the terra nullius doctrine. ${ }^{21}$ It is evident that there is a conspicuous affinity with regard to legal geographical discrimination between the Ainu people and the Bedouin people by both the Japanese and the Israeli governments.

\section{(3) Recent controversial issues}

The recent controversial issues in Hokkaido include the repatriation of stolen Ainu ancestral remains and treasures, the environmental injustice, such as the Nibutani Dam and the Monbetsu industrial waste sites, and the need for protection of indigenous knowledge. All of them show Ainu property discrimination in its broader sense. First, Ainu ancestral remains and cultural artifacts were stolen from almost all Ainu tombs across Hokkaido most prominently, or notoriously, by Hokkaido University Professor Kodama. ${ }^{22}$ More than 1,000 Ainu ancestral remains were kept in the repository house in the Hokkaido University campus, and then controversially have been consolidated at the ceremonial site of the Ainu Symbolic Space in Shiraoi that will be open in April, 2020. Several repatriation lawsuits have been filed since 2012, initially by Urakawa Ainu descendants. However, Hokkaido University has rejected their position by taking an individualistic property notion of "next of kin", which does not match with the indigenous collective notion of property. Eventually the University started inconsistently started accepting repatriation settlements one after another.

Second, with regard to the environmental injustice to the Ainu people, the world-famous Nibutani Dam was completed in 1997 and has caused eco-damage. Construction of the dam was never changed despite a judicial finding of illegality in the Nibutani Dam decision, ${ }^{23}$ mentioning cultural rights of International Covenant on Civil and Political Rights (ICCPR) Art. 27. The court could not require the destruction of the constructed dam,

\footnotetext{
${ }^{20}$ By the loose application of the Hokkaido Underdeveloped State Land Transfer Act of 1897 and its related regulation.

${ }^{21}$ For the detail of the Ainu lands confiscation process, see, Tadashi Takizawa, Land Law Reform as the Hokkaido Development in Early Meiji Era and the Ainu Lands: Focusing on Art. 7 of Hokkaido Land Ordinance of 1872, 51 HistORICAL STUDIES OF HoKKAIDO U. 1, at 9, 10, 14-16, 25-25 (2011).

22 Prof. Sakuzaemon Kodama's (1895-1970) office in Hokkaido University was surrounded by abundant Ainu remains and cultural artifacts. Now his Ainu remains were moved to the repository house in the campus, and then controversially have been consolidated in Shiraoi from 2020, but his cultural artifacts have been kept in the Northern Ethnic Materials Museum in Hakodate as the "Kodama collection," without noting anything about their provenance.

${ }_{23}$ The Sapporo District Court decision on March 27th, 1997, 1598 HANREI JiHOU 33.
} 
unlike the American court decisions regarding Columbia and Klamath Rivers. ${ }^{24}$ But ironically many local Ainu residents faced a Catch-22 situation and worked as day laborers, due to their poverty, on this project that submerged their sacred cultural sites of Chinomishiri. This is a systemic problem and a similar dam named the Biratori Dam, is now being constructed. As for the Monbetsu industrial site completed in 2012, it was constructed by cutting Mt. Shumaritapkop, a sacred mountain for Ainu people there. The Monbetsu project might block the anadromous salmons along Toyooka River due to water contamination. ${ }^{25}$

\section{B. (Case 2) Property System as the Basis of Korean and Taiwanese Colonization (1) Korean Peninsula}

The Korean Land Investigation Project was conducted from May 1910 through October 1918 by the Land Investigation Agency that was established in March 1910 at the Korean Governor's Office. It was based on the Land and House Investigation Regulation of 1906. The project was performed based on the land property system of landlords, while it neglected the traditional farmers' rights. During this process, there was the dramatic increase or invasion of Japanese landlords: The number spiked up from 692 in 1909 to 6969 in 1915.

A noteworthy feature of the Korean Land investigation Project is the disparity between landlords and farmers: Among 2.65 million farmer units, there were only 0.08 million landlord units as opposed to 0.52 million (independent farmer units), 1.04 million (semi-independent farmer units), and one million (rental farmer units) among 9.29 million farmers (1916) (3\% vs. 97\%). In this investigation process, unproven lands were confiscated as (Japanese) state land ${ }^{26}$.

\section{(2) Taiwan}

In Taiwan, the similar project was performed from 1898 through 1910s by the Taiwan Land Registration and Investigation Regulation in 1898. The Taiwan project was based on a land system depending on the small size over large scale landlords, whose lands were acquired by Taiwan Bank. This approach allegedly enhanced the modern capitalism.

Both these land investigation projects attacked the pre-modern multiple property system of feudal era in quest of modern property law concepts. Admittedly, these projects contributed to efficient land management, addressing what modern theorists label the problem of anti-commons. ${ }^{27}$ However, it is important to recognize that there was a negative side of colonialism in this process of geographically disparate property investigation projects by way of the expansion of the Japanese land property system and that it was prone to confiscation and exploitation of colonized lands.

\footnotetext{
${ }^{24}$ On the judicial activism in the United States despite its insufficiency over environmental issues, see, e.g., Jim Robbins, How Long Before These Salmon Are Gone? Maybe 20 Years, The New York Times, September 17th, 2019, D1, D2. See also, Kunihiko Yoshida, Yurok Tribe's Water and Fishing Rights: Their Adversity and Prospect with Compared to the Ainu People, 780 HOGAKU SEMINAR 51-57 (2020).

${ }^{25}$ See, Kunihiko Yoshida, Reparations Problems of the Ainu Indigenous People: From the Civil Law Perspective (Japan: Sapporo Free School Yu, 2012) 33-.

${ }^{26}$ For details, see, Hiroshi Miyajima, Research on the Korean Land Investigation Project (Tokyo: Oriental Culture Research Institute of Tokyo University, 1991).

${ }_{27}$ Michael Heller, The Tragedy of the Anti-commons: Property in the Tradition from Marx to Market, 111 HARV. L. REV. 621 (1988).
} 


\section{Other Discriminatory Legal Geography Cases}

\section{A. (Case 3) The Infamous Utoro Urban Squatter Case $^{28}$}

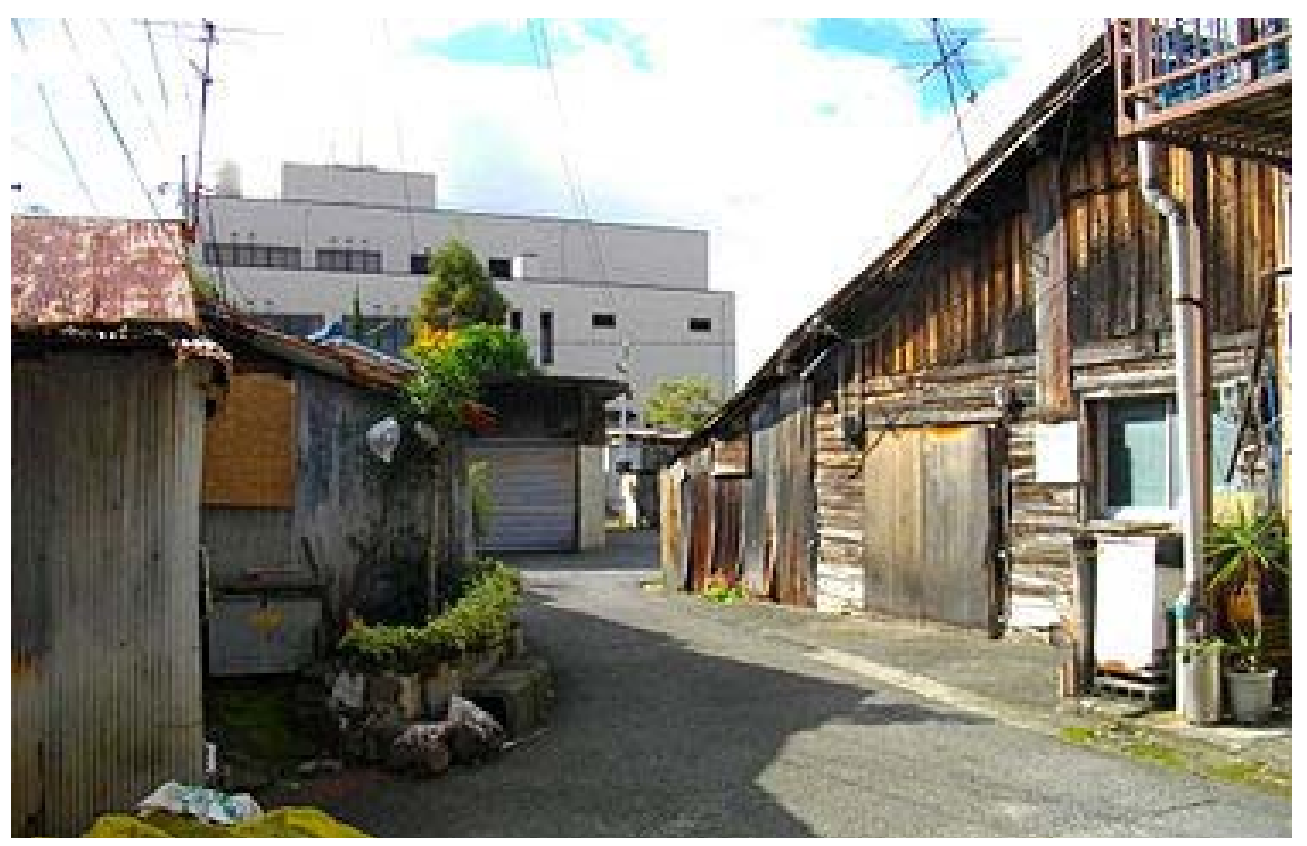

Figure 4. A bunkhouse for slave laborers in Utoro.

Since the end of WWII, roughly 600,000 ethnic Koreans residing in Japan ${ }^{29}$ have faced discrimination and marginalization. They did not return to Korea even after they lost Japanese nationality postwar. Some of them lived in various places as 'urban squatters', their residential status ignored, most notably in the Utoro area of Uji City in Kyoto Prefecture and in the Nakamura district of Itami city near Osaka Airport. Nowadays almost all of such geographically discriminated areas have disappeared.

Here is the Utoro story. More than 200 residents in the Utoro area in Uji City, who had worked as slave laborers for the construction of Kyoto Airport from 1942, faced eviction lawsuits from February 1989 and failed in November 2000 at the Japanese Supreme Court. Their land titles were neglected. They could not obtain a water supply until the 1980s. Legally their housing should have been protected by adverse possession, but the Japanese judiciary did not recognize their claim. ${ }^{30}$ In the mid-2000s, their miserable situation was exhibited in the East Asian international housing conference that we organized. Finally, after several decades, their plight attracted attention among ordinary Korean citizens. ${ }^{31}$ Now they are moving to public housings from April 2018 with the financial help of the Korean government.

\footnotetext{
28 E.g., Masaki Saitoh, Problems of Utoro Residents in Kyoto, in: Kazuo HaYAKawa, Kunihiko YoshidA ET AL. EDS., Homelessness, Evictions AND Living Welfare (Tokyo: Shinzan Pub. Co., 2007) 143-.

29 Now it has been decreasing to 559,903 in June 2019, according to the Ministry of Justice, https://www.e-stat.go.jp/stat-search/files?page $=1 \&$ layout $=$ datalist\&toukei $=00250012 \&$ tstat $=000001018034 \&$ cycle $=1 \&$ year $=2019$ $0 \&$ month $=12040606 \&$ tclass $1=000001060399$.

30 For my legal analysis, see, Kunihiko Yoshida, Property, Housing Welfare and Reparations Problems in Multicultural ERA (Tokyo: Yuhikaku Pub. Co., 2006) 472-

31 For discussions with Korean scholars, see, HAYAKAWA ET AL. EDS., supra note 28, at 159-.
} 


\section{B. (Case 4) Environmental Degradation of Okinawa and the Geographically Disparate Application of Law}

\section{(1) The Futenma and Takae cases}

Moving on to environmental law, legal discrepancies in Okinawa are noteworthy. Remarkably about three quarters $(74 \%)$ of the U.S. military bases in Japan are concentrated in the small Island of Okinawa in spite of its smallness, consisting of $0.6 \%$ of Japan's land area. According to Prof. Tetsuya Takahashi, this represents Japan's "system of sacrifice". ${ }^{32}$

Accordingly, the geographical legal application is uneven here. It seems that the case law regarding noise prevention, such as the Osaka International Airport case, ${ }^{33}$ cannot be applied here. The campus of Okinawa International University was hit by a U.S. helicopter from Futenma U.S. military base in 2004. The roar of Osprey aircraft, audible 24 hours a day from the rooftops of university buildings, is unimaginable. Furthermore, the controversial North Training Center as an exercise airport for Osprey pilots has now been constructed in the northern residential area named Takae, by destroying rain forests despite the strong opposition of local residents. ${ }^{34}$ The geographical discrepancy here stems from the U.S.-Japan Status of Forces Agreement of 1960.

\section{(2) The Henoko case}

Another famous controversial place is Henoko, the site of a new U.S. military base. Due to its construction over the ocean despite the opposition of local residents, the region's marine environment is now being seriously damaged. Okinawa's former Governor late Takeshi Onaga rejected permission for the landfill for its construction. However, the Fukuoka High Court considered his act illegal, even though Governor Onaga's action was highly political and discretionary. ${ }^{35}$ The Chief Judge Toshirou Tamiya emphasized the judiciary role, ruling that the "cover" of the governor's discretion should be removed. This judicial activist stance is exceptionally unusual and contrasts markedly with the generally conspicuous trend of judicial passivism in administrative cases, such as the rejection of claims regarding the illegality of administrative inaction for leftover poisonous weapons in northern China and related tort damages cases ${ }^{36}$.

\footnotetext{
32 Professor Takahashi argues that Okinawa can be considered the "inland colony". See, Tetsuya Takahashi, The System of SACRIFICE: FuKUSHIMA AND OKINAWA (Tokyo: Shueisha, 2012) 162-.

33 The Japanese Supreme Court decision on Dec. 16th, 1981, 35(10) MinsHu (Japanese Supreme Court Case Reporter) 1369. The lower court decision, i.e., Osaka High Court decision in November 1975, recognized all the plaintiffs' assertions: an injunction against night flights from $9 \mathrm{pm}$ through $7 \mathrm{am}$ and damages for noise in the past and in the future. After the government's appeal, the Supreme Court rejected the injunction for procedural reasons: the injunction should have been pursued through administrative litigation as opposed to civil law (tort law) litigation.

34 On this issue, see, e.g., the movie named "Love Okinawa at Henoko, Takae and Futenma" (2012) by directors Yukihisa Fujimoto and Asako Kageyama.

${ }^{35}$ Fukuoka High Court (Naha Division) decision on Sept. 16th, 2016, 2317 HANREI JiHOU 42. It was endorsed by the Japanese Supreme Court on Dec. 20th, 2016. It also admitted procedurally the Central Government's cancellation of Governor Onaga's decision on March 26th, 2020

${ }^{36}$ See, for example, Kunihiko Yoshida, War Reparations Issues regarding Left-over Poisonous Weapons in Northern China, in: Kunihiko Yoshida, East Asian Civil Law Scholarship and Disaster, Housing and Ethnic Reparations (Part. II) (Civil LAw Theory vol.6) (Tokyo: Shinzan Pub. Co., 2017) 223- (originally HoKKaIDo LAw Rev. Vol. 67 No. 2,3 [2017]).
} 


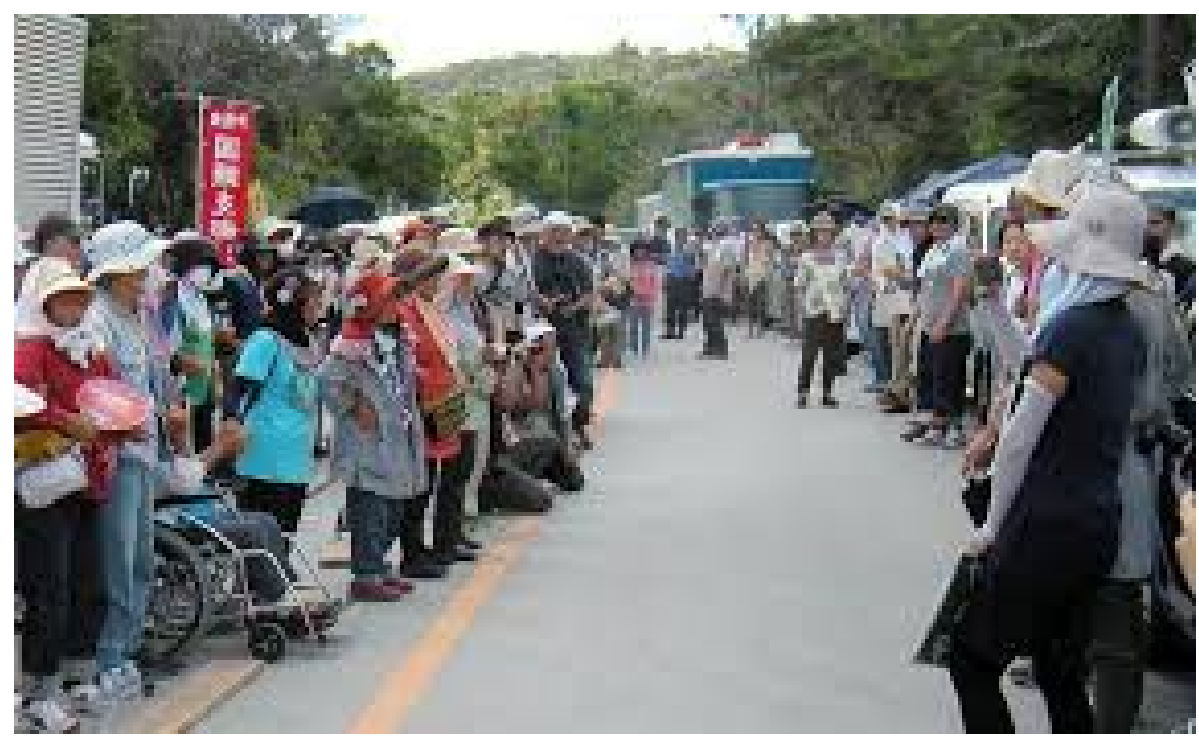

Figure 5. Local residents opposed to the construction of the Northern Training Center.

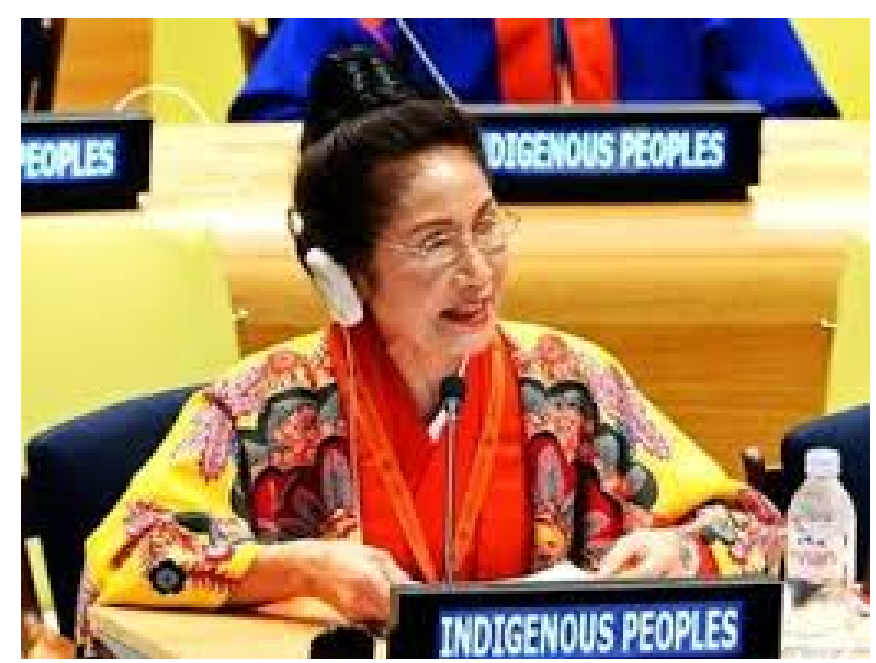

Figure 6. Senator Itokazu at the UN: She retired from the Japanese Diet in July 2019.

This undemocratic decision-making process and the subsequent uneven judicial process, that simply accepts Japanese central government decisions despite the strong opposition of local government and residents, must be critically analyzed from the legal geography perspective. The discriminatory treatment could be related to the racial disparagement. Among anthropologists, it is well known that the people of the Ryukyu island chain are a separate indigenous people, even though the Japanese government continues to deny it. ${ }^{37}$ Thus, Okinawan people, historically and even nowadays, have been racially oppressed, discriminated and marginalized geographically.

\footnotetext{
37 The assimilation policy towards the Ryukyu people started from the colonization of Ryukyu Kingdom by the Meiji Government in 1872, named "Transfer of Ryukyu Islands" in Japan. See also, the negative comments of the Japanese Government issued in August 2016, with regard to the Recommendation of the CERD on September 26th, 2014 (CERD/C/JPN/CO/7-9), https://www.mofa.go.jp/mofaj/files/000190405.pdf.
} 
Not many Japanese know that the United Nations, especially its Committee on the Elimination of Racial Discrimination (CERD), has requested that the Japanese government should admit the Ryukyu people as a separate indigenous people since October 2008, and that the CERD issued its final decision and statement to Japan in September 2014. The Japanese government has been constantly inactive, even though Senator Keiko Itokazu herself made an appeal at the UN shortly before the committee's conclusion, for the right of political participation under UNDRIP Art. 18, describing the geographical discrimination with regard to the U.S. military bases. $^{38}$

\section{C. (Case 5) Unrecognized Voluntary Evacuees Regarding the Fukushima Radiation Disaster ${ }^{39}$ (1) Definition and background}

The unrecognized voluntary evacuees regarding Fukushima radiation disaster is another good example of violent legal geographical discrimination in recent years.

As is evident from a comparison of the two maps below, many people were exposed to high level of radiation even though they were living outside the mandatory evacuation zone set by the Japanese government, which still adamantly abides by the standard of $20 \mathrm{mSv}$, not five $\mathrm{mSv}$ which was the case for mandatory evacuation after Chernobyl nuclear disaster. ${ }^{40}$ Naturally many of them fled their hometowns in Fukushima to avoid radiation for the safety of their families.

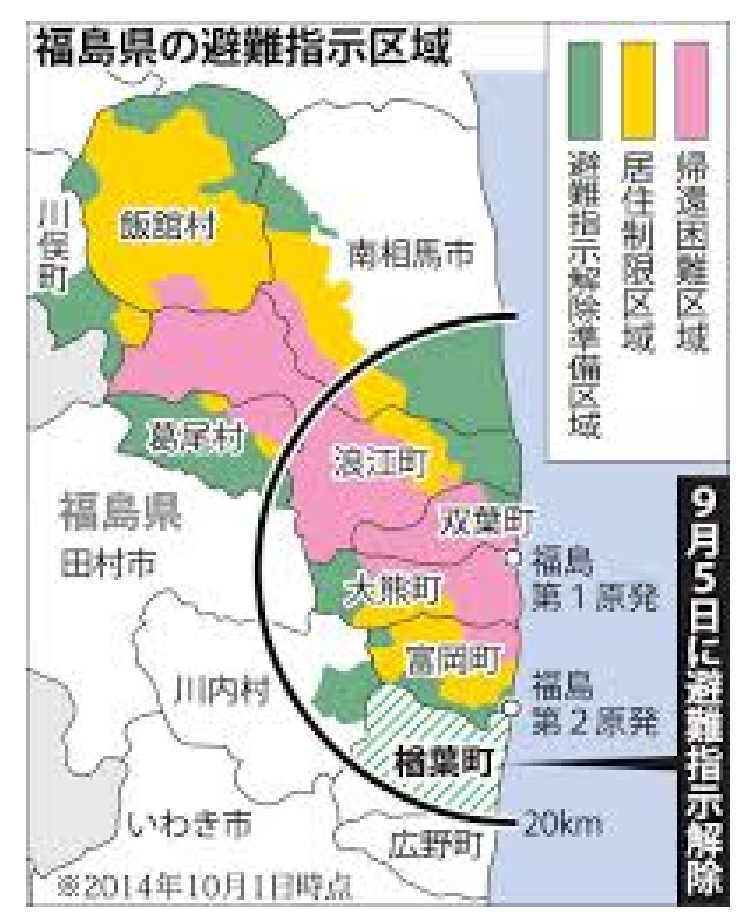

Figure 7. Mandatory Evacuation zone in Fukushima.

\footnotetext{
38 See, OKINAWA TiMES, September 24th, 2014.

39 For the detail, see, Kunihiko Yoshida, Problems and Challenges for "Voluntary Evacuees" with regard to the Fukushima Radiation Disaster, 67(4) HOKKAIDO L. REV. 1288-1305 (2016).

${ }^{40}$ For the detail of the evacuation policy after the Chernobyl disaster as compared to the Fukushima radiation disaster, see, Kunihiko Yoshida, Some Suggestions from the Chernobyl Nuclear Disaster Recovery from the Housing/Welfare Perspectives: Absolute Difference between Chernobyl and Fukushima Daiichi Disasters, 1026 NBL 33 (2014).
} 


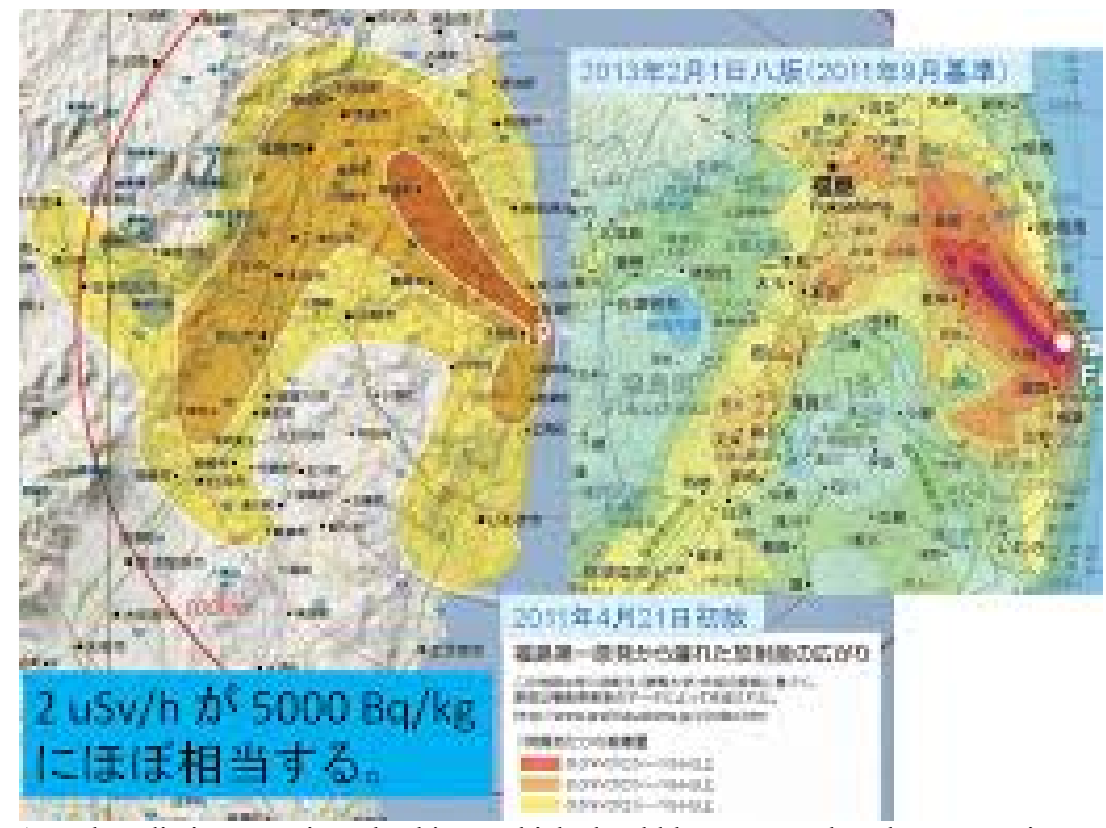

Figure 8. The Actual Radiation Map in Fukushima, which should be compared to the Evacuation Zone Map above (Figure 7) (The permission has been gained from Prof. Yukio Hayakawa who drew these maps): It shows that the radioactive plume moved northwest at first to the Fukushima City area and further from the TEPCO's explosion site, and then went down through Koriyama City southwest to the Kanto region. Its area was much wider than the evacuation zone.

Those people have been called "voluntary evacuees", or evacuees residing outside of the mandatory evacuation zone. But their serious problem was their limited remedies set by the Fukushima Nuclear Damage Compensation Council, contrary to those within the mandatory evacuation zone, even though voluntary evacuees also spent considerably for their new lives across Japan. Furthermore, they also faced eviction from their temporary housing after the end of March 2017. Many of them filed a class action to compensate for their actual expenditure, but the judicial protection has been limited. The judiciary has not played any role to remediate the geographical gap made by the administrative branch.

\section{(2) The number of voluntary evacuees}

The number of voluntary evacuees has not been officially recognized, but was estimated at 60,000 to 80,000 in 2012, and had decreased to 25,000 (13,000 families) by the end of October 2015. In Hokkaido, there were 3,220 in the summer of 2011, down to 2,125 in February 2016. According to the report of the Disaster Recovery Agency in Japan, the number further decreased to 1177 in February 2017. ${ }^{41}$

There must have been many more people who wanted to avoid radiation, but who did not evacuate for financial reasons or due to oppressive community power to not leave their hometown and abandon their relatives.

\section{(3) Discrepancy between mandatory evacuees and voluntary evacuees in terms of remedies}

Damages for voluntary evacuees were discussed for several months before the Council issued the first amendment in December 2011. Mr. Seiichi Nakate and Mrs. Takako Shishido, then representatives of Hokkaido Voluntary Evacuees Residential Association, spoke of their suffering to council members on October 20th,

\footnotetext{
${ }^{41}$ See, https://www.pref.fukushima.lg.jp/uploaded/attachment/210749.pdf. The recent big decline could be due to dwindling financial assistance for voluntary evacuees and communal pressure and request to return to their hometowns from relatives and acquaintances in Fukushima.
} 
$2011^{42}$. At an earlier stage, the civil law scholars on the council, such as Prof. Yoshihisa Nomi, chairperson of the council, and Prof. Tadashi Ohtsuka, were sympathetic to the voluntary evacuees' situation and positive with regard to their protection, but over the course of discussions, they followed Mr. Shun'ichi Tanaka, a former chairperson of the Nuclear Regulation Authority, in rejecting most of their compensation. The result in the first amendment of December 2011 was: 400,000 JPY (US\$3,600) for pregnant women and children per person with TEPCO's voluntary addition of 200,000 JPY (US\$1,800) $(600,000 \mathrm{JPY}$ (US\$5,400) in total per person) and $\underline{80,000 \mathrm{JPY}}$ (US\$720) for other persons for the year of 2011 as their lump sum remedies, and its payment was done by TEPCO in February 2012.

The Council added nothing more for voluntary evacuees in the second amendment in March 2012, although following the second amendment, TEPCO added the voluntary payment in December 2012 by 120,000 JPY (US\$1100) for pregnant women and children and 40,000 JPY (US\$360) for other persons. These payments were still far below those provided for the mandatory evacuees, who are granted a minimum of 100,000 JPY (US\$910) per month per person. ${ }^{43}$

\section{D. (Case 6) The Cambodian Civil Code's Case: A Recent Legal Transplant From Japan}

The legal transplant of the Japanese Civil Code in Cambodia after the turn of the 21st century has been generally praised. The new Cambodian Civil Code was made in December 2011, with the great help of Japanese civil law scholars spearheaded by Prof. Morishima ${ }^{44}$ from March 1999. The codification assistance process for the Cambodia Civil Code was as follows: (1) The project of codification assistance regarding Cambodian laws was initiated by the Japan International Cooperation Agency (JICA) in March 1999. It held workshops every month with subsequent mutual discussions among lawyers in both countries; (2) the Cambodian civil code draft was presented to top leaders of the Cambodian Government in March 2003; (3) the Cambodian Civil Code was passed by the Cambodian legislature in November 2007; and (4) the Statute for Applying the Civil Code was enacted in May 2011 and took effect in December 2011.

However, the discrepancy between law on the books and law in action there should be analyzed carefully. Prime Minister Hun Sen, who used to be a member of Khmer Rouge, and now holds a long-term dictator status, has recently mentioned that no rule of law should be needed in Cambodia. ${ }^{45}$ For example, the land concessions from his government, which are inconsistent with the Japanese Civil Law, are opaque concurrent transactions and allegedly comprise one tenth to one third of the whole land. I suspect that they might lead to corruption if their purpose is related to development rather than minority protection. ${ }^{46}$ For example, the recent report on the construction of Dara Sakor International Airport, whose military purpose is hidden and opaque, indicates that the project is based on the land concession of 2008. That concession covers 20 percent of Cambodian coastline

\footnotetext{
42 The proceedings of their statements at the $15^{\text {th }}$ commission meeting is available at: http://www.mext.go.jp/b_menu/shingi/chousa/kaihatu/016/gijiroku/1313194.htm.

${ }_{43}$ For the detail, including a new way of calculating damages for voluntary evacuees as their equitable remedies, see, KUNIHIKO Yoshida, East Asian Civil Law Scholarship Facing Disaster, Housing, and Ethnic Raparations (Part III) (Civil Law THEORY Vol. 7) (Tokyo: Shinzan Pub. Co., 2019)76-, 82-, 103, 110-, 122-.

44 Prof. Akio Morishima (1934-), a graduate of Tokyo University in 1958, was a civil law professor of Nagoya University from 1961 to 1996, then of Sophia University from 1996 on. He has been a director of Global Environment Research Center since 1999. He also has been a leader of the Codification Assistance Projects for Southeast Asian countries, starting with Viet Nam in 1996.

45 According to my conversation with JICA staff in Phnom Penh during my visit there in July 2018.

${ }^{46}$ The conversation with Mr. Issei Sakano at the ALSA meeting in Osaka on December 14th, 2019 was illuminative in this respect.
} 
through a 99-year land lease to the Chinese Union Development Group. ${ }^{47}$ Furthermore, Chinese economic dominance, especially regarding the construction of many dams along the Mekong River in Laos and Cambodia, is noteworthy and might cause a serious environmental damage to Viet Nam and to Cambodia itself according to the recent newspaper report ${ }^{48}$. In this sense, Cambodia has a serious environmental problem (which is also the field of Prof. Morishima) as an issue of global economic network. It should be analyzed critically within the scope of substantive civil law.
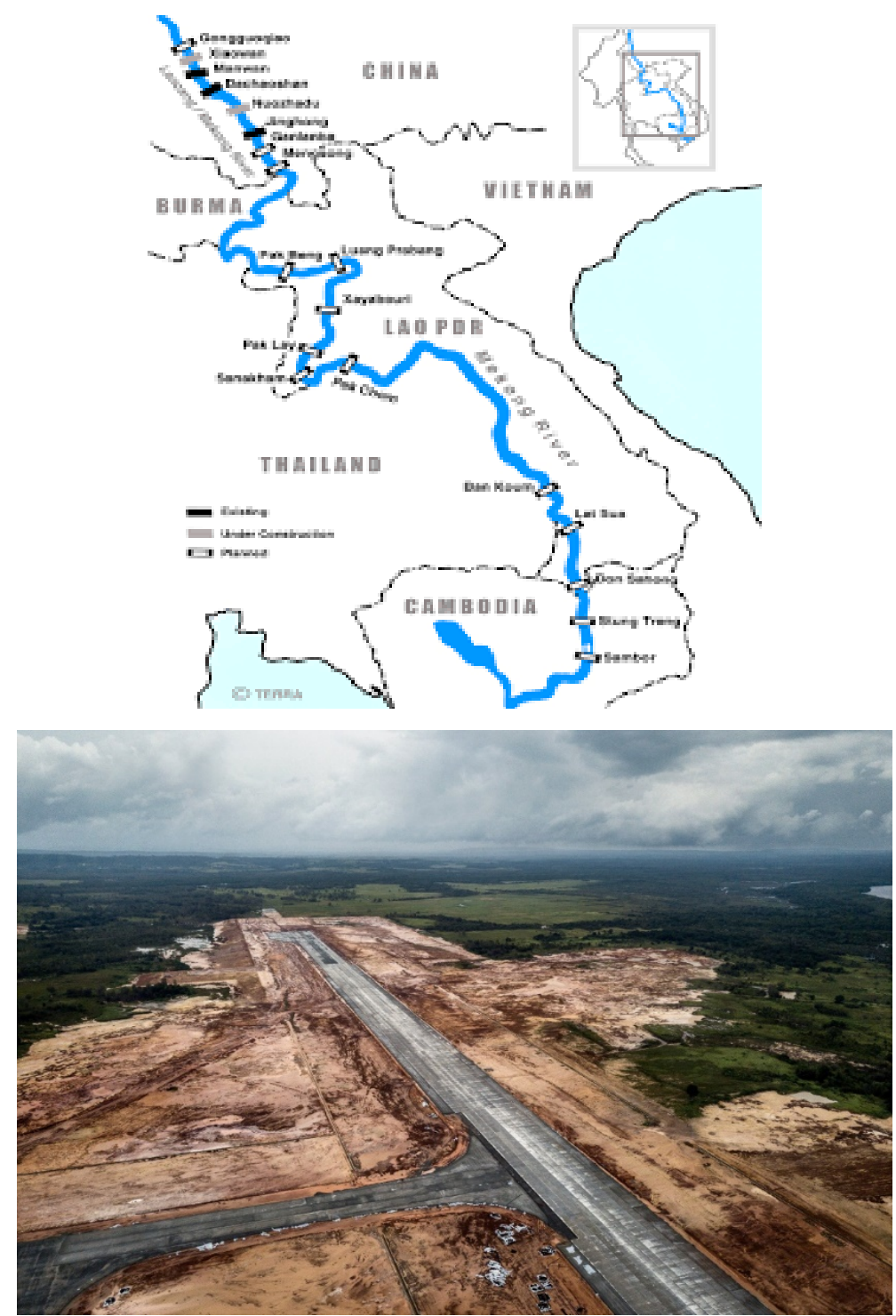

Figure 9. Dara Sakor International Airport under construction after destroying jungles in Southwestern Cambodia) (Source: the New York Times photo on 12/26/2019).

\footnotetext{
47 See, Hannah Beech, A Jungle Toehold for China: Some Analysts Believe Beijing Is Building Military Outposts in Cambodia, The New York Times, InTERnATIONAL EDITION, December 26th, 2019, pp. 1, 6.

${ }^{48}$ E.g., Hannah Beech, "Life on the River Is Finished": System of Chinese Dams Could Deplete Lifeblood of Expansive Mekong Region, THE NeW York TIMES, INTERNATIONAL EDITION, October 14th, 2019, pp. 1, 2.
} 


\section{Conclusions}

\section{A. Seriousness of Environmental Issues Outside of the Traditional Civil Law Apparatus}

The legal geography method, in contrast to linear "legal transplant" discourse, is sensitive to power relationships and context/culture-embeddedness. The importance of critical analyses from the marginalized neglected minorities' perspectives should be emphasized. Furthermore, there should be a need for recognition of global issues, especially climate change and related environmental issues, including the displacement of indigenous peoples. These issues should be recognized as essential in the 21 st century as one of the most serious situational consequences of global economic network of power relationship. They have been neglected by the traditional civil law legal apparatus. For example, much of the recent drastic increase of wildfires in the Amazon rainforests of Brazil under the Bolsonaro administration can be explained by Brazil's export of soybeans and beef to China ${ }^{49}$.

\section{B. The Need for Protection of Indigenous Peoples' Rights in the 21st Century: Insufficient Enforcement of the UNDRIP}

Indigenous peoples, by their lifestyles and their philosophies, are supportive of the 21st century environmental protection and a sustainable food supply. Accordingly, enforcement of the UNDRIP in 2007 is an essential world obligation.

However, better UNDRIP enforcement is insufficient in the face of the destruction of indigenous communities and related environmental degradation due to global capitalism. Indigenous peoples have been killed most notably in Latin America when they defend their lives. Even the UN rapporteur has been intimidated. ${ }^{50}$ For example, rights to the indigenous lands, territories and resources; the right to redress by means of restitution, just and fair compensation; the right to the conservation and protection of environment; and the right to their cultural heritage, traditional knowledge and traditional cultural expressions (UNDRIP Articles 26, 28,29 , and 31) should be protected as global civil law issues, if the global legal transplant of civil law is taken seriously. According to the traditional legal framework, indigenous peoples have been historically marginalized by the modern "nation-state based" scope limitations. ${ }^{51}$

\footnotetext{
49 On this international global environmental problems, see, for example, Clifford Krauss, David Yaffe-Bellany and Mariana Simoes, Burned by Broken Promises: A 2009 Deal Was Meant to Stop Ecological Arson in Brazil's Amazon, but It Didn't, THE New York Times, International Edition, October 12th-13th, 2019, at 1, 2; Clifford Krauss, Whiff of Money in the Smoke: In the Amazon Rainforest, Ranchers Set Fires to Clear More pasture for Cattle, THE New York Times, InTERnATIONAL Edition, November 6th, 2019, at 1, 2; Matt Sandy, The Amazon under Bolsonaro: "Lawless": In Brazil, the First Year under a New President Has Seen Soaring Deforestation, The New York Times, InTERnational Edition, December 10th, 2019 , at 5.

${ }^{50}$ NYT(IE) Editorials, Earth's Defenders Are Being Killed: Those Who Resist Powerful Industries that Savage Ecosystems and Drive People Off Their Land Face Death and Fear, The New York Times, InTERnATIOnAl Edition, August 3rd-4th, 2019 , at 11 [The New York Times, August 8th, 2019, at A22] (164 defenders killed in 2018 [201 in 2017]).

51 In this regard, Kunihiko Yoshida, The Regional Implementation of the International Human Right Law and the Protection of Indigenous Peoples' Rights: Focusing on Inter-American and African System, in: COMPARATIVE LAW BETWEEN JAPAN AND BRAZIL (Tokyo: Shinzan Pub. Co., 2019) 461-, esp. 519-.
} 


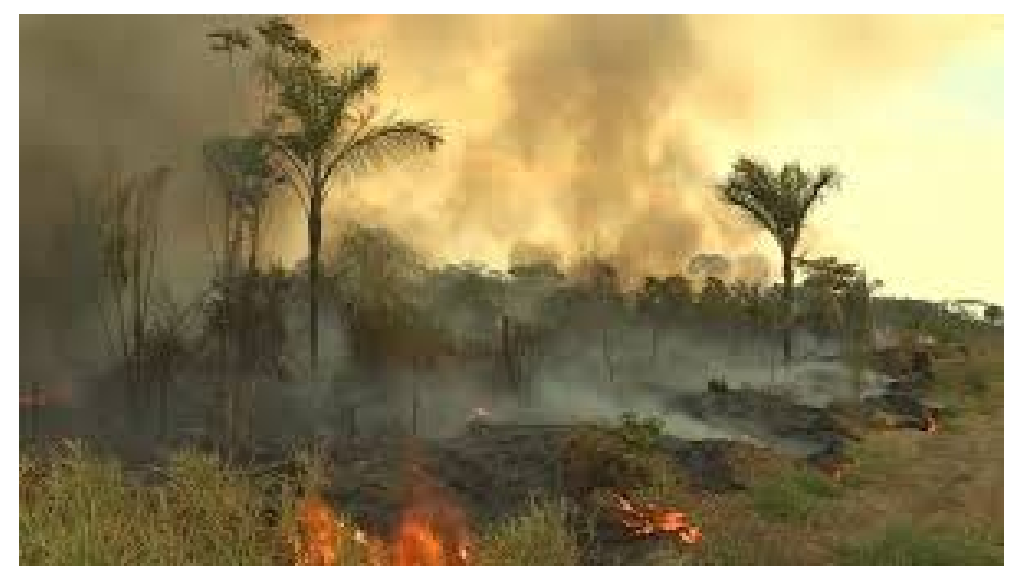

Figure 10. 2019 Brazilian rainforest wildfires attributable to China-Brazil economic relations.

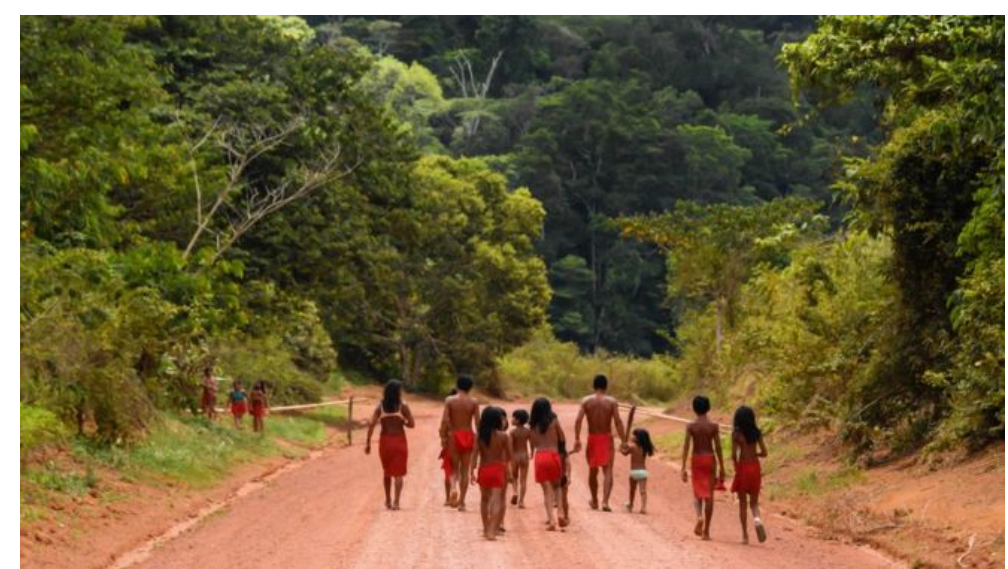

Figure 11. Displaced indigenous people in Brazil.

\section{The Need for the Regional Implementation of the International Human Right Law: The Possibility of the Inbound "Legal Transplant" of the World Standard}

As already mentioned by Dean Anaya, the previous special rapporteur of UNDRIP ${ }^{52}$ in the East Asia or in the Southeast Asia, the regional implementation of international human right law is missing. We should recognize that this situation is unusual and exceptional compared to the Inter-American system, the African system, and the European system that all control human right issues in each domestic law internationally.

Even though the international economic coordination efforts, such as Free Trade Agreement (FTA) in general, and Economic Partnership Agreements (EPAs) between the EU and the African, Caribbean, and Pacific Group of States (ACP), and the Agreement on Trade-Related Aspects of Intellectual Property Rights (TRIPS Agreement) (1995-) more specifically, for example, have been developing at various levels, the internationalization of the human right protection still stagnates in this Asian area. Thus, the domestic law regarding basic human rights in each country frequently becomes self-complacent. It is outdated, far behind the world standard. For example, the Japanese government is adamant in rejecting comfort women and slave labor reparations-the background of the recent deadlock of the Japan-Korea relationship. Likewise, the Japanese

\footnotetext{
52 See, Hurst Hannum, Dinah L. Shelton, S. James Anaya \& Rosa Celorio, International Human Rights: Problems of Law, Policy, AND Practice (6th ed.) (New York: Wolter Kluwer, 2018) 172.
} 
Government, despite the warning from the United Nations, ignores the homelessness issue and the plight of vulnerable people after disasters despite the warning from the United Nations, and still hides the past injustice to the Ainu people even after the signing the UNDRIP in 2007.

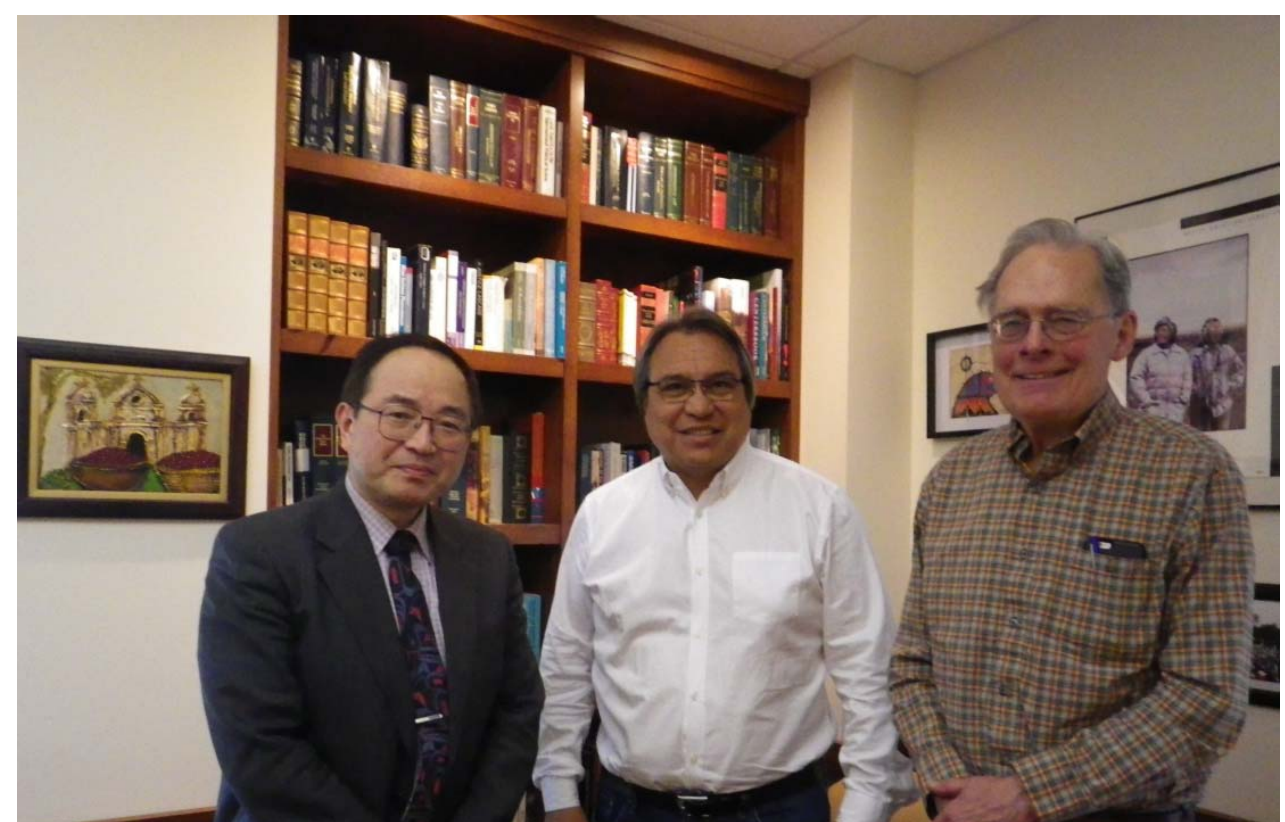

Figure 12. Dean J. Anaya at University of Colorado Law School with Professor Charles Wilkinson, an expert on US Federal Indian Law, in the Dean's suite.

Against this backdrop, we should take seriously the need for the inbound "legal transplant" of world standards, most notably the UN legal instruments, and we should start to establish the regional implementation system in East Asia and Southeast Asia. Relatedly, we should take humble heed in this field to the U.S. Congress accusation statement bills which remind us of this systemic problem, ${ }^{53}$ because they indicate the importance of human right issues. Thus, I think, the respect for human right values in each country by virtue of inbound international human rights law, geographically broaden the legitimacy as a country committed to democracy and human rights in international community. ${ }^{54}$

\footnotetext{
${ }_{54}$ For example, the U.S. bills regarding the comfort women issues in 2007, and Hong Kong and Uighur problems in 2019.

${ }^{54}$ Professor Eric Yamamoto of University Hawaii, Richardson School of Law, also stresses this point in his recent international human rights articles, especially in the East Asian context. For example, Eric Yamamoto et al., Korean "Comfort Women" Redress 2012 Through the Lens of U.S. Civil and Human Rights Reparatory Justice Experiences (with Lee), 11 J. KOREAN LAW 123, at 139- (2012); Unfinished Business: A Joint United States and South Korea Jeju 4.3 Tragedy Task Force to Further Implement Recommendations and Foster Comprehensive and Enduring "Social Healing Through Justice (with Pettit and Lee), 15 ASIAN PAC. L. \& POL. J. 1, at 44- (2014).
} 